Hannah Mae Loke

\title{
DAUGHTERS OF HEAVEN A Law and Literature Analysis
}

Submitted for the LLB (Honours) Degree

Faculty of Law

Victoria University of Wellington

2014 


\section{Table of Contents}

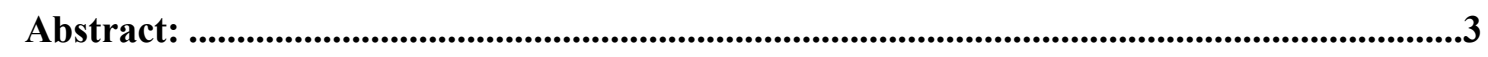

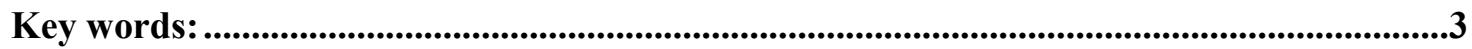

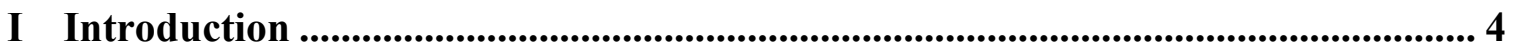

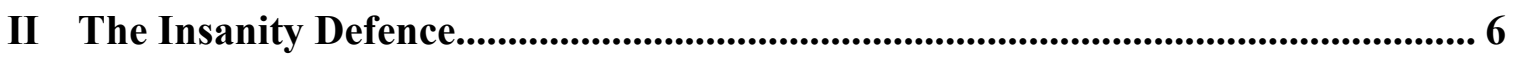

A The Law and its Application to the Facts ..............................................................................6

B Depicting Law in Daughters of Heaven.....................................................................................8

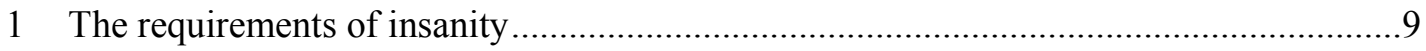

C Depicting Insanity in Daughters of Heaven ..........................................................................13

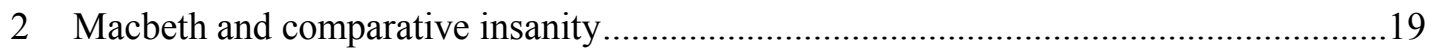

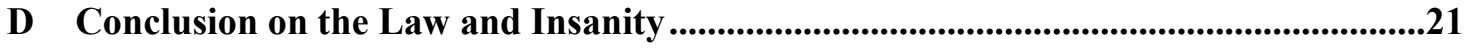

III Social opinions and influence on the law ................................................... 22

E Social Background...............................................................................................................22

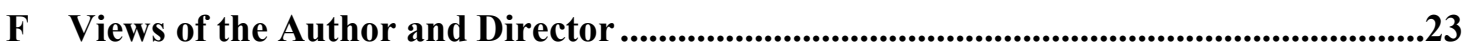

G The Influence of the Media.......................................................................................................27

H Social Influences on the Law...............................................................................................29

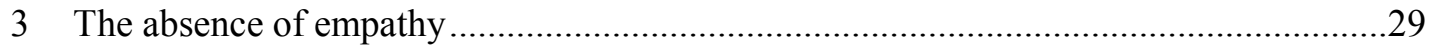

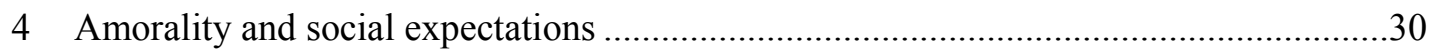

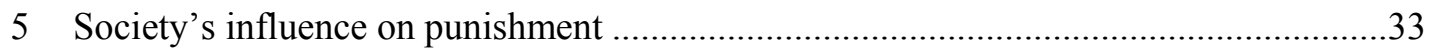

I Forster's Judgment on the Law ................................................................................................34

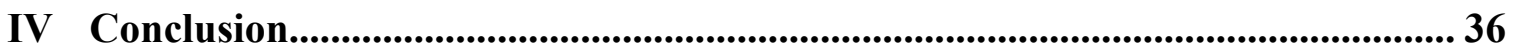

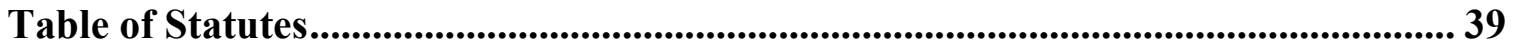

Table of Cases.............................................................................................................. 39

Bibliography ........................................................................................................................ 39 


\section{Abstract:}

This paper conducts a law and literature review of the play Daughters of Heaven by Michelanne Forster. The text portrays the murder of Honora Rieper by Pauline Parker and Juliet Hulme, and the trial that ensued. This paper explores the play's depiction of the insanity defence in light of the law of the time and in the context of Christchurch society of the time. The social influence on the application and interpretation of the law is explored via the character of Bridget in particular, who is clearly influenced by Forster's own views. Forster does not make an explicit 'good or bad' judgment on the law, but her shock and disbelief of the events is evident throughout the text. Her use of legal concepts is predominantly for entertainment purposes, and as such is mostly basic and undetailed. This does not, however, detract from Daughters of Heaven from being a dramatically gripping and compelling work.

\section{Key words:}

Daughters of Heaven, law and literature, Pauline Parker, Juliet Hulme, insanity. 


\section{Introduction}

This paper will conduct a law and literature analysis of the play Daughters of Heaven by Michelanne Forster. The play is a fictionalised account of the true events surrounding the 1954 murder of Honora Rieper by her daughter Pauline Parker and Pauline's friend Juliet Hulme. The events of their murder trial is utilised to retrospectively retell the meeting of the two girls, their growing friendship, and their plot to kill Mrs Rieper. Forster also incorporates verbatim passages from court reports, which were published daily in the newspapers at the time. The text also draws on Pauline's diary entries to demonstrate the strangeness of the pair, and arguably also to imply that they were insane when they committed the murder. Much of the text however, is fictionalised.

The fictional representations of legal issues in Daughters of Heaven are the focus of this paper. The failed insanity defence and the influence of social opinion on the law and its applicability are pertinent legal issues within the play. The relationship, and indeed the divergence between law and morality is also an underling presence. Forster expresses these issues using varying intensities of fiction. This analysis will also consider whether Forster is passing judgment on the legal system and law of the time from a modern, removed perspective.

While the references to law within the play are largely factually correct, they merely brush the surface of the legal importance and intricacies. The insanity argument raised by the defence counsel was particularly complex and required much medical expert evidence. This is not canvassed in detail in the play; which is understandable, when 
writing for a non-legally or medically trained audience. As such, the law serves as a background to the dramatic action, rather than the foremost concern of the text.

In Daughters of Heaven Forster is able to convey the social opinions of the crime, as well as how opinion influences the way the law is seen to operate. This is illustrated to a greater extent than the detailing of any strictly legal matters. Christchurch was a heavily British- influenced society at the time of the murder. The shocked reactions of the Christchurch public influenced both the process and the media coverage of the girls' trial, and also arguably their sentence. This lead to a thirst for punishment and widespread condemnation of the girls' actions.

Forster views the events through a relatively unbiased eye. Her emphasis is largely on the girls' skewed moral perspectives, which makes them seem misguided and thoroughly unlikeable. Their actions seem justifiable by their own moral compass, but objectively are still morally shocking. Therefore, the insanity defence is portrayed as somewhat of a hopeless case, as it was perceived at the time. The underlying morality of the girls' actions, while strictly legally irrelevant, greatly influenced the approach taken by the girls' legal team, and also Forster's approach to fictionalising the events. 


\title{
II The Insanity Defence
}

\section{A The Law and its Application to the Facts}

In both reality and in the dramatized version of their story, Pauline and Juliet made statements to police admitting to the murder, without first obtaining legal advice. ${ }^{1}$ Because of this admission, they could not plead innocence. The only viable option for the girls' defence teams was to argue a defence of insanity.

As at 1954, the year of the murder, the law for an insanity defence was contained in subsection (3) of section 43 of the Crimes Act 1908. It provided:

\begin{abstract}
A person labouring under specific delusions, but in other respects sane, shall not be acquitted on the ground of insanity under the provisions hereinafter contained unless the delusions caused him to believe in the existence of some state of things which, if it existed, would justify or excuse his act or omission.
\end{abstract}

Insanity is not a medically recognised concept, but is rather "a legal term of art". ${ }^{2}$ While medical evidence is important evidence to a finding of insanity, it is not determinative, and is ultimately the decision as to whether a defendant is insane is a question of fact. ${ }^{3}$

\footnotetext{
${ }^{1}$ Peter Graham So Brilliantly Clever: Parker, Hulme and the Murder That Shocked the World (Awa Press, Wellington, 2011) at 162.

${ }^{2}$ Andrew P Simester and Warren J Brookbanks Principles of Criminal Law (4th ed, Thomson Brookers, 2012) at 316.

${ }^{3}$ Ibid, at 356 .
} 
The defence of insanity in the 1908 Act, and also in the current 1961 Act, is based upon the rules arising from the M'Naghten's Case. ${ }^{4}$ The classic Rule states that "[ $\mathrm{t}$ ] e establish a defence on the ground of insanity, it must be clearly proved that, at the time of committing the act, the party accused was labouring under such a defect of reason, from disease of the mind, as not to know the nature and quality of the act he was doing; or if he did know it, that he did not know he was doing what was wrong." 5

According to Simester and Brookbanks, "M'Naghten demonstrates... that a person may know precisely what he or she is doing and even been aware that he or she is committing a criminal act, yet be excused because firmly-held delusions have compelled him or her to act as he or she did." In an article on the Parker and Hulme case, Bruce Harding believes that " $[\ldots]$ this formulation almost perfectly describes the mindset of Pauline Parker and Juliet Hulme", and yet the jury did not find them insane. ${ }^{7}$ This seems somewhat contradictory. In their own opinion, the girls' peculiar moral beliefs justified their actions. This, however, was not the result under the law.

In order to reconcile the law and the facts on this point, it is suggested that Simester and Brookbanks refer to medically proven delusions, rather than morally compelled ones. The morality or otherwise of a person's actions is therefore not at issue. "The principal

${ }^{4}$ (1843) 10 Cl \& Fin; 8 ER 718; [1843-60] All ER Rep 229 (HL).

${ }^{5}$ Simester and Brookbanks Principles of Criminal Law, above $\mathrm{n} 2$, at 323-4.

${ }^{6}$ Ibid, at 324.

${ }^{7}$ Bruce Harding "When the 'corpus juris' meets a corpus delicti: The appearance and representation of Law's violence as purveyed in the Hulme-Parker trial [1954] and narrated in Peter Jackson's Heavenly Creatures [1994]" [unpublished] at [15]. 
difference between the M'Naghten Rules and s 23 is that the New Zealand Parliament has defined insanity in terms of the accused's capacity to understand the nature and quality of an act or omission, or to know that it was morally wrong; whereas the M'Naghten Rules were concerned with the accused's actual knowledge of those matters." ${ }^{8}$ While this statement refers to the current version of the insanity defence under the current Crimes Act, the analysis is still applicable to the previous version of the defence under the old Act. So, according to New Zealand law, as long as a defendant has the mental capacity to appreciate the nature and quality of their act, they cannot be found insane.

The law of insanity is highly technical, and its proof requires much evidence. It has significant dramatic potential, which is drawn out in Daughters of Heaven. It must be acknowledged that while a dramatic work may have an educational purpose, the predominant aim is usually to provide entertainment and also to earn the author an income. Using heavily technical and legal material is likely to be at odds with entertaining an audience with minimal interest in legal formalities. Therefore, in Daughters of Heaven an in-depth approach to the law is eschewed in favour of using legal concepts with little detailed explanation, and which are largely of secondary importance to audience entertainment.

\section{B Depicting Law in Daughters of Heaven}

Pauline and Juliet's trial serves as a framework for the structure of the play. The courtroom scenes begin partway through Act I Scene 2, where Crown Prosecutor Alan

${ }^{8}$ Simester and Brookbanks Principles of Criminal Law, above n 2, at 327. 
Brown asks the jury to put what they have heard about the case aside. The next scene is a flashback to the girls playacting in Juliet's bedroom, some time before the murder takes place. Subsequently, much of the play is structured this way; evidence is given, an address is made, or a conversation during cross-examination is then followed by a flashback to pre-murder events. This continues until the middle of Act Two, where the action between the courtroom and the 'external world' becomes largely contemporaneous.

Forster uses the murder as one of the two climaxes of the play; the other is the jury declaring the girls guilty of murder. The legal climax of the verdict is also one of the peaks of dramatic tension. This reflects the inherent dramatic potential of the law. In particular, using the basic framework of an insanity defence as a dramatic narrative is a way of incorporating law in an accessible manner. The use of the trial as the 'structuring device' drives action and reaction in the play. This could imply that, structurally, law conforms to our longing for order, and for a cumulative and structured narrative.

\section{The requirements of insanity}

Forster drew on court transcripts in writing the courtroom passages of Daughters of Heaven. She acknowledges that courtroom testimony and Pauline's diary quotations are taken from court reports as printed in local newspapers at the time of the trial. ${ }^{9}$ Comparing Daughters of Heaven to these sources, much of the dialogue is verbatim, or

\footnotetext{
${ }^{9}$ Michelanne Forster Daughters of Heaven, (Victoria University Press, Wellington, 1992) at 14.
} 
almost so. ${ }^{10}$ It follows that Forster's presentation of the legal approaches to the text is usually legally and factually correct. However, the intricacies of the insanity defence, the relationship between medical evidence and legal requirements, and the extensive terminology can become rather overwhelming at times, without fuller explanation.

Forster makes some effort to explain the requirements for an insanity defence to an audience who are likely to be unaware of the legal implications of such a label. Terence Gresson, Juliet's defence counsel, explains to Mrs Hulme that: ${ }^{11}$

Gresson: $\quad[\ldots]$ We must prove, beyond a shadow of a doubt, that the accused did not know the nature and quality of their act. Whatever labels I have to use I will, to show the girls are - and were - deluded and living in a state of unreality.

The phrase 'nature and quality of their act' is drawn directly from section 43 of the Crimes Act. It is used again when Doctor Medlicott is cross-examined by the Crown Prosecutor Alan Brown. This passage illustrates how, in the text, the full legal implication of Medlicott's testimony is unclear: ${ }^{12}$

Brown: Did these two young persons, when they attacked Mrs Rieper, know what they were doing?

\footnotetext{
10 See: "The Trial of Pauline Yvonne Parker and Juliet Marion Hulme August 1954" Star Sun (Christchurch, August 1954).

${ }^{11}$ Forster Daughters of Heaven, above n 9, at 73- 4.

${ }^{12}$ Ibid, at 77.
} 
Medlicott: $\quad$ They knew what they were doing.

Brown: Did they know the nature and quality of their act?

Medlicott: $\quad$ They did.

Brown: Did they know they were wrong according to the law?

Medlicott: $\quad$ They did, but they did not recognise the law.

Bridget: $\quad$ But the law is law. Like God is God. You can't remake the universe to suit yourself. The universe is, and you fit into it. Isn't that so? $[\ldots]$

This passage builds on the earlier dialogue from Gresson. While the phrase 'nature and quality of the act' is used several times in the text, the full legal meaning of the term not explained. In reference to the 1961 Crimes Act, which uses the same phrasing, Simester and Brookbanks note that "The phrase does not involve any consideration of the accused's moral perception, his or her knowledge of the moral quality of the act... it is necessary for the accused to prove that he or she did not know what he or she was doing, or did not appreciate the consequences of the act, or did not appreciate the circumstances in which he or she was acting". ${ }^{13}$

This distinction was crucial during the trial, but little is made of it within Daughters of Heaven. The moral consideration versus the issue of understanding of consequences or circumstances is a complex issue, and is largely assessed by psychologists and other professionals. However, Pauline and Juliet's moral perception of their actions and their ability to appreciate consequences are inextricably linked within the text. Several

\footnotetext{
${ }^{13}$ Simester and Brookbanks Principles of Criminal Law, above $\mathrm{n} 2$, at 348.
} 
situations depict the girls' utter belief that their invented new moral code is the 'right' one; for example, they attempt to subvert the Ten Commandments, and also create their own 'Royal Law'. ${ }^{14}$ A moral subversion of social norms allows Forster to build drama whilst emphasising the very factors which are not crucial to an insanity defence.

Bridget's remark "But the law is law. Like God is God" delineates a simplistic view of what the law is; a simple question of right or wrong. The insanity defence, however, is more nuanced than this. It partially rests on whether the defendant appreciated that their act was wrong, not merely whether it was wrong in fact. After referencing the specific legal test in the text, Bridget's observation reflects the innate moral difficulties with this reasoning for a non-legally educated audience. It also inadvertently displays the binary approach to the case that was widely adopted by the media at the time; the phrase 'mad or bad?' became the summation of the defence and prosecution's respective arguments. ${ }^{15}$

As well as 'nature and quality of the act', further legal and medical terminology is used but remains unexplained. The defence team relied on folie à deux, or communicated insanity, to aid their argument. In the text, Crown Prosecutor Brown uses this phrase without further technical elaboration. The surrounding discussion, however, creates enough context for an audience to deduce the broad meaning of the phrase: ${ }^{16}$

\footnotetext{
${ }^{14}$ Forster Daughters of Heaven, above n 9, at 38 and 20 respectively.

15 See, for example, "Mrs Parker" (8 May 2014) Radio New Zealand < http://www.radionz.co.nz/national/programmes/mrs-parker>.

${ }^{16}$ Forster Daughters of Heaven, above $\mathrm{n} 9$, at 77.
} 
Brown: $\quad$ Have you ever heard of two insane people combining to commit a crime?

Medlicott: $\quad$ It is quite within the possibilities of the folie à deux paranoia to join in and plan the committing of a crime.

Brown: $\quad$ You believe they are grossly insane and certifiable?

Medlicott: Absolutely.

In referencing folie à deux, Forster hints at further complexities of law without subjecting the audience to a full explanation. The phrase is undoubtedly impressive and adds to the already heavy legal vocabulary. Again, Forster uses legal terms to impress upon the audience the gravity and complexity of the law, whilst aiming principally to entertain and allow the viewers to remain engaged with the plot.

\section{Depicting Insanity in Daughters of Heaven}

To those who knew them at the time, Pauline and Juliet were observed as being unusual girls. Pauline was sullen, angry and rebellious, and unable to participate in physical activities due to the effects of osteomyelitis, which she developed at a young age. ${ }^{17}$ Juliet was also excused from participating in physical activity at school due to suffering from tuberculosis and having weak lungs. She was self-assured, imaginative, and the envy of many of her classmates for her good looks and poise. ${ }^{18}$ Although she could have had her choice of friends Juliet chose to isolate herself, save for Pauline. They were an odd pair, but seemed to find solace and companionship with each other.

${ }^{17}$ Graham So Brilliantly Clever, above n 1, at 84-89.

${ }^{18}$ Ibid, at $90-91$. 
Forster's depiction of the girls' supposed insanity is partially informed by Pauline's diary entries, which were used as evidence at trial, and were also reported in the court reports. The diary was used to depict Pauline, and therefore Juliet by association, as lacking an understanding of the gravity of their actions. In this extract, the girls confide in their diaries the plan to murder Pauline's mother, showing an alarmingly cool, yet warped logic: ${ }^{19}$

Pauline is writing in her diary. Her parents are in the room.

Pauline: $\quad$ Our main idea for the day was to moider Mother. This notion is not a new one, but this time it is a definite plan which we intend to carry out. We have worked it out carefully and are both thrilled with the idea. Naturally we feel a trifle nervous, but the pleasure of anticipation is great.

In her own bedroom, Juliet is writing in her diary.

Juliet: $\quad$ Gina is very excited, as am I. At last we begin to move towards the final culmination of our dreams. Out consciences are clear. Great love requires great sacrifice.

The Rieper's lounge.

Pauline: I shall not write the plan down here as I shall write it up when we carry it out - I hope. Peculiarly enough I have no qualms of conscience.

${ }^{19}$ Forster Daughters of Heaven, above n 9, at 50. 
This scene demonstrates the girls' understanding of the consequences of their actions, but a lack of ability to see the moral 'wrongness' of their plans. The dramatic potential of Pauline confiding her dark thoughts in her diary while her intended victim is in the same room enhances the sinister nature of the moment. Under the applicable law, a failure to appreciate the morality of your actions did not constitute insanity. Here, however, Forster uses the girls' diary entries to depict their strangeness and immorality, in an attempt to imply insanity. From a legal perspective, the awareness of the immorality is totally irrelevant to a case of insanity, but dramatically the depiction of immorality seems to enhance it. This is an example of the full legal implications being dampened to further the dramatic purposes within Daughters of Heaven.

In the scene above the girls display their cold, calculating behaviour, which also seems lucid. Yet Forster maintains a sense that the girls are somewhat unusual, if not insane. In particular, Pauline's explanation of her 'insanity', on paper, is overly analytical and overthought. When being performed, the actress could choose how to take into account the written directions and to what extent Pauline appears lucid and calm. On a plain reading, however, Pauline seems to be far too logical to indicate insanity.

Pauline and Juliet's calm demeanour is juxtaposed with a stereotypical depiction of insanity in order for Forster to inform the audience that their behaviour seems unusual for persons who have confessed to murder. Bridget asks “. . . how can you prove a body's insane if he's not sitting there, gibbering and foaming at the mouth? By hiring a fancy 
psychiatrist, that's how." ${ }^{20}$ Contrasting a medically clichéd version of insanity with Pauline and Juliet's supposed insanity refutes the stereotype, and expands the audience's view of what insanity may mean in a legal sense.

The girls' cold logic is exhibited during their interviews with Medlicott. While the girls are able to answer Medlicott's questions clearly, their air of vagueness contrasted with rationality is unsettling. For example, Juliet's self-importance underlies her rambling responses to Medlicott in this scene: ${ }^{21}$

Juliet: $\quad$ I would be an absolute moron not to know murder was against the law. I don't believe we've done anything wrong. I know we've broken the law but morally we are without fault. $[\ldots]$

Medlicott: $\quad$ So this 'Fourth World' that you speak of is a real, physical place?

Juliet: $\quad$ We saw it at Port Levy. It's metaphorical in the sense that it's not exact but it's definitely there.

Medlicott: Couldn't this world be part of your imagination?

Juliet: $\quad$ I know it's real.

Juliet's admission of her awareness that murder is against the law is supplementary evidence against her supposed insanity. Furthermore, her fixation on the morality of her actions is technically irrelevant to a finding of insanity. It does, however, make her less

${ }^{20}$ Forster Daughters of Heaven, above n 9, at 67.

21 Ibid. 
likable, and gives the audience an uneasy feeling. Juliet's attitude and self-importance was a concern for the defence, as was the social hysteria surrounding youth offending. This hysteria point will be further discussed later.

Probably because of this confusing mix of oddness and rationality, the defence lawyers felt that an insanity defence would be difficult to prove. Pauline and Juliet did not testify in their own defence. While this would have created an interesting twist in Daughters of Heaven, Forster stays true to the actual events: ${ }^{22}$

Bridget: $\quad$ The trial went on six days. Everybody and his dog testified- but not Juliet or Pauline. They sat there, at the heart of the murder, silent as two stones. Their own lawyers wouldn't let them talk because they were too clever- if you heard them talking you'd know they weren't crazy. See? Simple logic.

Peter Graham also highlights how the girls' behaviour would have adversely affected their defence: ${ }^{23}$

The lawyers could not possibly call Juliet or Pauline as witnesses. There was no legal obstacle to either girl giving evidence, but their rudeness, their arrogance and conceit, their abusiveness...would alienate the jury. The fact they crowed about having killed Mrs Parker would appal anyone who had to listen to them.

\footnotetext{
${ }^{22}$ Ibid, at 70 .

${ }^{23}$ Graham So Brilliantly Clever, above n 1, at 169-170.
} 
The girls' unpleasantness strongly influenced society's opinions, and subsequently, it seems, the likeliness they would be found insane. This flow-on effect seems inconsistent with the law. A societal view, while condemning a person's actions, should not dictate the applicability or heavy-handedness of the law. Further, the fact that the girls actually wished to be considered insane consequently lessened the likeliness of them being factually found so. In the play, this is discussed in court during Medlicott's crossexamination: ${ }^{24}$

Brown: $\quad$ Dr Medlicott, are the accused insane from a legal point of view?

Medlicott: $\quad$ To my mind, they are.

Brown: During your interviews they tried to impress upon you they were insane?

Medlicott: $\quad$ On several occasions, yes.

Brown: Why would they want to be held insane?

Medlicott: $\quad$ I don't know clearly.

Brown: $\quad$ Have you formed any theory?

Medlicott: I think it's quite possible they thought being insane might lessen the time of their detention.

Brown: But the girls knew the penalty before they killed Mrs Rieper?

Medlicott: At my first interview with Parker on June 27 she said she knew murder was considered wrong.

Brown: Well, that is one admission anyway.

\footnotetext{
${ }^{24}$ Forster Daughters of Heaven, above $\mathrm{n} 9$, at 75 .
} 
This passage demonstrates how the defence attempted to paint the accused as insane by using the girls' own admissions of insanity. Graham says, "Surely it would be difficult to persuade the jury that two girls who were mad might pretend to be mad?"25 The girls' own behaviour and mental states were working against them; both their obtuseness and insistence of their insanity were the exact opposite of how a jury would expect insane people to behave.

\section{Macbeth and comparative insanity}

One of the methods Crown Prosecutor Alan Brown used to attempt to show that Pauline and Juliet were insane was a comparison between the girls' behaviour and that of Lady Macbeth. Alan Brown was one of the memorable characters of the trial, and enjoyed drawing on various literary examples and quotations as allusions for the case at hand. ${ }^{26}$ Brown's allusion to Macbeth is replicated in Daughters of Heaven; possibly because it is one of the more colourful moments of a grim trial. The reference allows Forster to compare the murderers with a character who was famously calm in the aftermath of a murder, until she became wracked with guilt: ${ }^{27}$

Brown: $\quad$ You placed a considerable importance on the girls' cool demeanour after they got over the sudden shock of the killing.

Medlicott: I think it is an aspect of their condition.

$[\ldots]$

\footnotetext{
${ }^{25}$ Graham So Brilliantly Clever, above n 1, at 187.

${ }^{26} \mathrm{Ibid}$, at 174-5.

${ }^{27}$ Forster Daughters of Heaven, above n 9, at 76-7.
} 
Brown: $\quad$ [...] Did not Macbeth murder Duncan at the instigation of Lady Macbeth?

Medlicott: $\quad$ Yes.

Brown: Was she mad?

Medlicott: $\quad$ No. These girls have no contrition. Lady Macbeth was stricken with remorse.

This passage is taken almost verbatim from Brown's exchange with Doctor Bennett, another of the medical witnesses for the defence. ${ }^{28}$ The reference to Lady Macbeth lends itself well to inclusion in fictionalised account of the events, for purely dramatic purposes, but also for comparative emphasis of conduct. Lady Macbeth incites her husband to murder King Duncan. She is later stricken with guilt, and in the famous sleepwalking scene she attempts to wash imaginary blood from her hands: ${ }^{29}$

“Out, damned spot! out, I say! - One: two: why, then, 'tis time to do’t. - Hell is murky! - [...] Here's the smell of blood still: all the perfumes of Arabia will not sweeten this little hand [...] come, come, come, come, give me your hand. What's done cannot be undone. - To bed, to bed, to bed."

Brown's reference to Lady Macbeth conjures an image of a frantic woman imagining the endless and futile washing of her hands. She is a woman who is clearly mentally impaired

\footnotetext{
${ }^{28}$ See "The Trial of Pauline Yvonne Parker and Juliet Marion Hulme August 1954", Christchurch City Libraries $<$ http://christchurchcitylibraries.com/heritage/digitised/parkerhulme/ $>$ at "Murder Charge: Hearing of Evidence Completed: Address to Jury Today" p 19.

${ }^{29}$ William Shakespeare Macbeth (Cambridge University Press, Cambridge, 2008) at Act 5 Scene 1.
} 
by guilt. By including Brown's reference in Daughters of Heaven, Forster harks back to Bridget's vision of the obviously insane; someone who is "foaming at the mouth" and feels remorse for their actions. ${ }^{30}$ This is starkly contrasted to the calculated calmness and obtuseness displayed by Pauline and Juliet immediately after the murder and during the trial. The portrayal of Lady Macbeth during the sleepwalking scene is made more powerful by the contrast to her earlier character. Before King Duncan's murder, Lady Macbeth is cool, calm, and the consummate host. In comparison to Pauline and Juliet, Lady Macbeth's decline is extreme and outwardly visible. Forster's portrayal of the teenage murderers reflects the opposite response.

\section{Conclusion on the Law and Insanity}

The law of insanity is used predominantly for dramatic purposes in Daughters of Heaven. The text's emphasis of morality within an insanity plea is contrary to what a strictly legal approach would consider relevant. This, however, allows an audience to form a strong opinion of the case; not necessarily based on law, but based on social norms. The girls' behaviour is consistently contrasted with what would be considered 'normal'; that is society's view of what is morally correct. They are also compared to other characters, such as Bridget, and external references in the form of Lady Macbeth. The behaviour of the accused, and the way society, and the audience, react also plays a role in how the law is perceived and carried out. This shows that the law does not operate in isolation, but is affected by societal influences and opinions.

\footnotetext{
${ }^{30}$ Forster Daughters of Heaven, above n 9, at 67.
} 


\section{Social opinions and influence on the law}

This section will explore society's opinion of the law and the murder. It will consider how society's views influenced the perception of how the law applied to Pauline and Juliet. The response was generally that of shock and horror, and this was how the crime was portrayed in the media. In turn, society's view may also have influenced the application of the law in practice, to a limited extent.

\section{E Social Background}

The murder of Honora Rieper occurred on the 22 of June 1954. While matricide is a shocking crime under almost any set of circumstances and social expectations, it was particularly shocking to 1950 's Christchurch. The city was heavily influenced by conservative British values and morals, and the locals were already concerned about the stability and welfare of their children.

In Parker and Hulme: A Lesbian View, Glamuzina and Laurie describe the features of Christchurch at the time of the murder. The Canterbury region had a "distinctive Anglican tone", and a reputation for being quintessentially English. ${ }^{31}$ Graham echoes these comments, stating "The Englishness of Christchurch and Canterbury was both an article of faith and a source of pride for many who lived there". ${ }^{32}$ Christchurch strived to emulate middle and upper class values, and people outside of these classes were

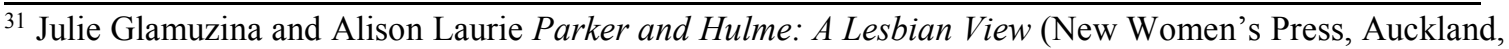
1991) at 29.

${ }^{32}$ Graham So Brilliantly Clever, above n 1, at 55 .
} 
oppressed and discriminated against. ${ }^{33} 34$ It is clear that Christchurch society was heavily influenced by conventional British ideals and social norms, making the murder all the more shocking.

Glamuzina and Laurie also refer to the 1954 Mazengarb report. A government enquiry was tasked with investigating "a rising wave of 'sexual delinquency', including homosexuality." 35 In the novel Obsession, which is based on the Parker-Hulme murder, a man contemplates why a group of young girls and boys would break into and rob a shop, kill a shopkeeper, and also sleep together in a sort of coven. ${ }^{36}$ This was based on a real situation that occurred in Wellington, which was another of the drivers for the Mazengarb enquiry. ${ }^{37}$ The Parker-Hulme murder could be seen as the terrible pinnacle of this hysteria surrounding teenage behaviour. "To many the evil act of Parker and Hulme was a prime example of the moral rot afflicting adolescents" and was "clear evidence of sickness infecting youth", 38

\section{F Views of the Author and Director}

Christchurch residents, and people worldwide, were shocked by the murder of Honora Rieper and the supposed homosexuality of the murderers. In the foreword and introduction to Daughters of Heaven, Michelanne Forster and Elric Hooper offer their

\footnotetext{
${ }^{33}$ Glamuzina and Laurie Parker and Hulme, above n 31, at 29.

${ }^{34}$ Ibid, at chapter 3 .

${ }^{35}$ Ibid, at 59.

${ }^{36}$ Tom Gurr and H. H. Cox Obsession (Fredrick Muller Ltd, London, 1958), at 12.

${ }^{37}$ Glamuzina and Laurie Parker and Hulme, above n 31, at 58.

${ }^{38}$ Graham So Brilliantly Clever, above n 1, at 173.
} 
own perspectives on the case and of these scandalous details. Hooper was the director of the first performance of the play at the Court Theatre in Christchurch. They describe their initial reactions to the case, and also the opinions of others when word spread that the murder was to be the subject of a dramatic work.

Hooper was a student at Canterbury University, and remembers students and staff being intrigued, disgusted and shocked by the events, and also by what others were saying about those events. He says "I heard the word 'lesbian' for the first time", and contemplates that “... as with so many others, the Parker-Hulme case was part of my education, loss of provincial innocence and the beginning of disillusion." ${ }^{39}$ Hooper felt that this "engrossing and bizarre story" was a tale worthy of dramatic interpretation, but was also aware that "the air was full of the sound of rising hackles and phrases like "bad taste'. ${ }^{, 40}$ It seemed that not everyone had detached from the events of almost forty years earlier; the shock factor surrounding the case was still present.

Forster was "both repelled and fascinated" by the case, but admits that she became more detached from the horror of the events as she continued to write. ${ }^{41}$ She comments, "The murder and society's subsequent punishment belong to history - for murder, however privately conceived, is a public act." ${ }^{\prime 2}$ This is perhaps an attempt to validate societal interest, and the artistic interest of those who wish to draw on the undeniably dramatic

\footnotetext{
${ }^{39}$ Forster Daughters of Heaven, above $\mathrm{n} 9$, at 7.

${ }^{40}$ Ibid.

${ }^{41}$ Ibid, at 10.

${ }^{42}$ Ibid, at 11 .
} 
story as inspiration. It may also be an acknowledgement of the public nature of crime. The comment and condemnation which crime provokes displays the full extent to which crime affects society.

Forster acknowledges the several layers to the story in her introduction. In answer to the question 'What is the play about?' she responded: ${ }^{43}$

"I find it nearly impossible to answer. [...] Look one way and it's the story of a provincial New Zealand town being turned upside down by a murder. It's the story of Christchurch in 1954, restrained and nice with implicit British attitudes about class and gender suddenly being confronted with evil.... Look another way and Daughters of Heaven is about love- that powerful emotion which sweeps reason and morality away in a crazy tide of two-ness."

Forster and Hooper's respective views inform the themes of the play, and also the messages communicated through the text and its performance. Law operates both in the foreground, during the trial scenes, and in the background as a device for propelling the action. The introduction and foreword, however, both indicate that heavily legal features operate mostly as background to the shock and drama that a murder offers to society.

\footnotetext{
43 Michelanne Forster "Five Questions About Daughters of Heaven" (July 2011), Playmarket $<$ http://www.playmarket.org.nz/sites/default/files/images/MISC/5\%20questions\%20about\%20daughters\%2 0of\%20heaven-draft\%202.pdf $>$.
} 
At a basic level, the story is that of Pauline and Juliet's relationship, their obsession with each other, and the world they create together. By looking through a wider lens society is inevitably drawn in, because, as Forster identifies, murder is a public act. Forster's own views of being repelled and fascinated certainly reflect the approach of the media, and also Christchurch society. Perhaps an audience is more able to easily identify with and understand a depiction of societal opinions than black-letter law. As a result, this social attitude of shock is depicted, rather than a critical approach towards the relevant law.

Forster expressly states her intentions not to make a social comment on the murder and the surrounding circumstances, yet one is clearly made in Daughters of Heaven. Through the character of Bridget, Forster represents the "opinions, attitudes and facts manifested in the city at the time". ${ }^{44}$ She states, "I didn't deliberately set out to thinking I must create a character which represents the conservative viewpoint of Christchurch citizens... [Bridget's] function in the play then became apparent over time." 45 She admits, however, that Bridget reflects her own "shocked and prudish take on the story". 46 Hooper comments that "The case brought out all the small-town prejudices one would expect to find in a place like Christchurch in 1954: anti-intellectualism, hypocritical disapproval of sexual misconduct, religious bigotry, and strange survivals of folk superstitions", and it is clear that Bridget embodies these values. ${ }^{47}$

\footnotetext{
${ }^{44}$ Forster Daughters of Heaven, above $\mathrm{n} 9$, at 8.

${ }^{45}$ Forster 'Five Questions', above n 43.

${ }^{46}$ Ibid.

${ }^{47}$ Forster Daughters of Heaven, above n 9, at 8.
} 
So, largely through Bridget, there exists an inbuilt device for critique and commentary of society and of the law. This reflection is only of one perspective; that of a shocked outsider with no empathy for the girls, and little understanding of the legal implications of the case other than the girls deserve to be punished. Bridget condemns Mrs Hulme's affair with Walter Perry, is shocked by Pauline and Juliet's supposed homosexuality, and comments with an 'uninformed eye' on the legal proceedings. Bridget's comment "But law is law. Like God is God" demonstrates how an uninformed, conservative Christian bystander might perceive law. ${ }^{48}$ This is one view, and cannot possibly encapsulate all opinions on the subject. But the generally stunned and condemning response to the murder, and the black-and-white view of the law, is how Christchurch was perceived and portrayed from within and without.

\section{G The Influence of the Media}

The influence of the media's portrayal of the girls, the trial and the 'social justice' of the case cannot be underestimated. As well as reporting incredibly detailed verbal exchanges and legal analysis, the newspapers inform the legal features of Daughters of Heaven. At the time Crown Prosecutor Alan Brown commented that although the case was widely publicised and was subject to international interest, this should not affect the jury's judgment of the defendants. As he states, it is a matter of law that this is so. This is also emphasised in the text: ${ }^{49}$

\footnotetext{
${ }^{48}$ Ibid, at 77.

${ }^{49}$ Ibid, at 18-19.
} 
Brown: $\quad$ Most of you will have read in the newspapers, and no doubt have discussed among you friends, the story of the crime. One of my duties is to ask you to forget all you have read or heard about the case, and indeed it is your duty to do so.

$[\ldots]$

You may pity the dead woman, the mother of the girl Parker who was brutally done to death, or you may feel pity for the accused in the dreadful situation they find themselves in today. These things have nothing to do with this trial at all. Sentiment and emotionalism have no part in British justice.

Bridget: $\quad$ British justice. Hah! There isn't a person in this court-room - or in the whole of Christchurch - who isn't salivating over every detail.

Brown's speech to the jury is taken almost verbatim from the court reports of his opening address in the Christchurch Supreme Court (as it was then). ${ }^{50}$ This passage demonstrates Brown's awareness of the potential influence of social views on the law and its interpretation. Brown strives to separate law and moral opinion. However, Bridget's remark blatantly demonstrates that the clamour for shock-inducing details would play a large role in how the case was perceived by the parties immediately involved and also by society at large.

\footnotetext{
${ }^{50}$ See "The Trial of Pauline Parker and Juliet Hulme", above n 28, at "Discovery of Body Described" 3.
} 


\section{H Social Influences on the Law}

\section{The absence of empathy}

Daughters of Heaven explores this relationship between the law and society's expectations and influences on the law. This is most noticeably voiced through Bridget, but the connection is also evident when characters uneducated in the law come into contact with it. For example, Mrs Hulme is convinced that Gresson should ply the jury for sympathy, rather than emphasise the potentially homosexual nature of Pauline and Juliet's relationship: ${ }^{51}$

Hilda: $\quad[\ldots]$ There are twelve simple men sitting on that jury. Our only hope is to make them feel pity.

Gresson: $\quad$ Pity, yes.

Hilda: I've thought about it for quite some time. Those twelve simple men may possibly be able to feel pity for two school-girls - but they will never find it in their hearts to feel pity for two homosexuals.

This conversation is fictional, and Forster uses it as a tool to reflect societal expectations and Hilda's attempt to use them to her advantage. Hilda believes that it is possible to 'get around' the law if only the jury feels sorry for the misunderstood, under-aged girls. Peter Graham also raises this thought, somewhat cynically: ${ }^{52}$

${ }^{51}$ Forster Daughters of Heaven, above $\mathrm{n} 9$, at 74.

${ }^{52}$ Graham So Brilliantly Clever, above n 1, at 180. 
If the jurors could be persuaded that Juliet and Pauline were suffering from a serious mental illness they might deal with them generously, without pedantic regard for the exact letter of section 43(2) of the Crimes Act. Wasn't that the beauty of the jury system the fact that justice could be tempered with mercy, that the common sense and humanity of the ordinary man in the street could prevail, if need be, over the strict letter of the law?

Appealing to the 'common sense and humanity of the ordinary man', in Mrs Hulme's eyes, meant suppressing the girls' homosexual tendencies. At the time homosexuality was seen as an indicator of insanity; perhaps this was a reflection of social norms on medical and legal requirements. The power of the social condemnation was such that even though it was thought necessary to draw on the girls' supposed homosexuality, in order to prove insanity, the shock factor would turn the jury and the public against them. Graham emphasises this when he says that Alec Halsam, Pauline's lead counsel "glossed over the crucial question of legal insanity in the hope that if the jury felt sorry for the girls they would overlook the legal niceties." 53 In Pauline and Juliet's case, the "quality of mercy" and law were incompatible; as it seems almost everyone involved realised. ${ }^{54}$

\section{Amorality and social expectations}

The divergence between generalised social moral opinions and the morality of the two murderers is consistently contrasted in Daughters of Heaven. Society's opinion of the

\footnotetext{
${ }^{53}$ Ibid, at 221.

${ }^{54}$ William Shakespeare The Merchant of Venice (Cambridge University Press, Cambridge, 2003) at Act 4 Scene 1.
} 
murder was made clear by the shocked reactions of the media, and the still-bewildered Christchurch residents who recalled the case years later. However, Pauline and Juliet displayed an outward disregard for societal norms, and seemed aware that their behaviour was not socially acceptable. "We had the right to do what we needed to in the interests of our own happiness." 55 By implication, it seems that the girls had little regard for what was morally or socially 'right'. Their interests were paramount, and any obstacle should and would be removed.

This attitude is reflected in Daughters of Heaven. The girls construct their own dream world of saints and gods, eschew Heaven in favour of their own created Paradise, and discuss breaking the Ten Commandments. While the Ten Commandments should not be equated with the law, they are thought to be a foundation basis for many Western legal systems under a naturalism approach to jurisprudence. ${ }^{56}$ Pauline and Juliet acknowledge the existence of God, but in a dismissive fashion, and in a manner that conforms to their imaginations. While they are playacting, Juliet declares, "All must cower before me and obey the wisdom of the Royal Law. The lively oracles of God are mine alone." ${ }^{57}$ They also teasingly discuss prostitution as a means to earn money to travel to America, which shocks Bridget and provokes her to cross herself in penance. ${ }^{58}$

\footnotetext{
${ }^{55}$ Forster Daughters of Heaven, above $\mathrm{n}$ 9, at 11.

${ }^{56}$ John T. McNeil "Natural Law in the Teaching of Reformers" (1946) 26 The Journal of Religion 168 at 168.

${ }^{57}$ Forster Daughters of Heaven, above n 9, at 20.

${ }^{58} \mathrm{Ibid}$, at 37.
} 
The flippancy with which Pauline and Juliet refer to social standards and the law demonstrates their awareness of conventional 'moral' right and wrongs, and their deliberate choice to elevate themselves above them. Forster chooses to show the girls discussing law and morality largely in the context of them roleplaying as various characters. They speak of a different world with different rules. It is therefore difficult to ascertain how much of their disregard for convention is fictional, and how much they truly believe in their alternate version of the law.

A clearer version of their moral compasses may be apparent through the diary entries. Pauline's entries are largely taken from the court reports. There was no concrete evidence that Juliet kept a diary, although this was strongly suggested, and possibly even 'obvious' ${ }^{59}$ If this was true, it was in all likeliness destroyed after Mrs Rieper's murder. Pauline's diary entry about the plan to 'moider Mother', as well as being used as evidence of insanity, strongly indicates apathy towards contemplating such an act. Pauline states, "Peculiarly enough I have no qualms of conscience." 60 This demonstrates her awareness of the 'wrongness' of the action, but she feels no uneasiness about such wrongness. In particular, Pauline's use of 'peculiarly enough' clearly indicates that she is conscious of her incompatibility with what she perceives to be the social norm.

\footnotetext{
${ }^{59}$ Graham So Brilliantly Clever, above n 1, at 181.

${ }^{60}$ Forster Daughters of Heaven, above n 9, at 50.
} 


\section{Society's influence on punishment}

The frenzy surrounding the case may also have influenced the punishment the girls received upon being found guilty. While the death penalty was an available punishment for murder, the age of the girls meant they were eligible for detention at Her Majesty's pleasure. Pauline was sent to Arohata in Wellington, while Juliet was sent to Mount Eden Prison in Auckland. ${ }^{61}$ It seems that "Prise them apart and separate them, that was the idea..."62 This reasoning is highlighted in Daughters of Heaven through several characters, including Bridget and the prison matron: ${ }^{63}$

Matron: $\quad$ Laugh now, go on. You won't be laughing once you're in prison.

Juliet: $\quad$ We can always find ways to keep ourselves amused.

Matron: $\quad$ You're not such a fool as to think you'll still be together?

Juliet: I've spoken to Mr Gresson and Dr Medlicott and it's all arranged.

Matron: $\quad$ They never put lesbians together. Regulations.

Juliet: $\quad$ We're a special case.

Matron: $\quad$ Tell that to the Judge. He'd love to hang you both.

Juliet: $\quad$ We're under age.

Matron: $\quad$ Lucky for you. He's a mean-minded teetotal Baptist shit and you won't find any ounce of sympathy from him - or any of the jury.

\footnotetext{
${ }^{61}$ Graham So Brilliantly Clever, above n 1, at 243-4.

${ }^{62} \mathrm{Ibid}$, at 82.

${ }^{63}$ Forster Daughters of Heaven, above n 9, at 72.
} 
The abhorrence, curiosity and shock of the general public, both in the immediate vicinity and worldwide, meant that it was all the more important that justice was seen to be done. Glamuzina and Laurie suggest that that because the girls were lesbians, which was a shocking fact at the time, may have driven the need to separate them. ${ }^{64}$ In Daughters of Heaven, social outrage is emphasised as being the dominant factor for punishment, rather than any offered legal reason. Again, this is an example of social and moral drivers outweighing strictly legal factors.

\section{Forster's Judgment on the Law}

Forster has stated that she did not intend to pass judgment on the crime or on the girls. ${ }^{65}$ She was, however, genuinely shocked and disturbed by the events. Her opinion was predominantly shared by Christchurch society. In the text it is echoed by Bridget, and also by minor characters such as the prison matron. These characters condemn the girls' actions, without real scrutiny of the legal application or repercussions.

So, while Forster has indicated she had no intention to make comment or criticism, this is inevitable through the voices of her characters. In particular, Bridget's point of view is consistently prioritised, especially when the girls' behaviour is something other than what would be considered the social norm. She is heavily judgmental when the girls demonstrate any part of their anti-social or unusual personalities.

\footnotetext{
${ }^{64}$ See Glamuzina and Laurie Parker and Hulme, above n 31, at chapter 7 for a discussion of this point.

${ }^{65}$ Forster 'Five Questions' above n 43.
} 
While Bridget in particular is critical of the social aspects of the crime, the characters, and therefore Forster, do not make significant comment upon the legal implications. The non-legal characters see the law as rigid and relatively inflexible; Bridget comments "But law is law", and Mr Gresson dismisses Mrs Hulme's belief that the law can be tempered with sympathy. ${ }^{66}$ Similarly, the 'legal' characters attempt to use the law to their advantage, but are restricted by the black-letter requirements. The lawyers struggle to fit the facts within a narrow insanity defence argument. The medical evidence is intended to be objective and unforgiving.

Forster's reference to the law underlies the dramatic action of the play. Law is something that must be abided by, and is not able to be questioned or abated by compassion. It is difficult to determine whether Forster believes this is a negative consequence, or whether this is simply law's function. Using law to drive the action allows legal undertones to permeate the entire text, without becoming dominant or overbearing. While the audience may leave the theatre without remembering the intricacies of an insanity defence, they will gain a sense that the legal system can produce a gripping and dramatically effective narrative.

Forster's reference to law and legal concepts is at a relatively basic level. She references some core aspects of the insanity defence, such as 'nature and quality of the act', but does not strictly link the implications of this to the narrative or to the outcomes of the girls' actions. The legal references are effective in that they remind the audience that the law is

\footnotetext{
${ }^{66}$ Forster Daughters of Heaven, above n 9, at 77 and 74.
} 
an ever-present driver of consequences, even though they are not explicitly explained. This is understandable in the context of writing for an audience who wish to be entertained, rather than legally educated. Forster's references to law drive a gripping narrative, without overbearing an outsider with jargon and technicalities. This makes for an effective, if not legally detailed, work.

\section{Conclusion}

Daughters of Heaven tells what is on the surface a seemingly simple story, with an underlying layer of social influences and turmoil. The legal aspects of the play are the most complex, and they are canvassed relatively broadly. The action is driven and framed around the events of the trial, and legal criteria are referred to infrequently. While Forster's legal references impress upon the audiences that legal concepts are important to the action and to the outcome of the trial, it is in a manner which emphasises the social reaction and effect of the crime, rather than technical phrases and criterion.

An insanity defence requires much medical evidence, which is not explored in depth within the text. Portraying insanity is made difficult, as the girls' behaviour is contrary to what would be stereotypically considered insane. Forster captures their calm, devious planning in several scenes. From a legal perspective, the way in which Pauline and Juliet behave would indicate that they are not insane. They demonstrate an awareness of their actions, and the potential consequences of their actions. The only potential issue is their consciousness of the morality of their actions, and their utter contempt for social norms. 
This is emphasized throughout the text. There are, however, no legal implications of this for an insanity defence.

The dramatic effect of behaviour that would not legally be considered indicative of insanity actually imposes this very impression on the audience. While difficult medical and legal terminology has largely been omitted from the text, the basic ideas and legal requirements are conveyed, but not impressed to a significant extent. This allows Forster to weave Pauline and Juliet's behaviour in such a way that they actually seem deserving of being deemed insane. The trial, and in particular the insanity defence, forms a strong underlying function of dramatic narrative, rather than having an informative or educational purpose.

The social influence of conservative Christchurch can be seen to reflect the law of the time, and how it applied to Pauline and Juliet. Bridget is the dominant voice of critique, community shock and anger at the murder and the girls' behaviour. However, she does not often directly comment on the law. When she does, it is in a matter-of-fact manner, viewing the law as an underlying, immovable force. Pauline and Juliet's arrogance, disregard for social norms and expectations is therefore all the more shocking.

The relationship between law and morality is constantly questioned throughout the text. It permeates the issues the defence team struggle with trying to prove insanity, and also the horror and shock of the community's response to the crime. The overlap between law and morality, and also the divergence between them, is exhibited through Pauline and Juliet's 
behaviour and how they disregard social norms in favour of their own rules. The requirements for an insanity defence display very clearly how law and morality do not always align; the girls' 'immorality' is not sufficient for them to be considered insane. However, in this particular case, it could be said that law and morality do align because the morally 'right' verdict was reached.

The murder of Honora Rieper remains one of the most shocking crimes in New Zealand's history. Daughters of Heaven makes full use of the dramatic potential of the events, while incorporating some important legal aspects to inform the audience to the extent that the trial and conviction make sense. Instead of emphasising legal requirements, Forster emphasizes the social influence and impact of the case. This makes for an entertaining, scandalous and intense work of drama, while remaining factually true to real life, in the broadest sense of the applicable law. 


\section{Table of Statutes}

1. Crimes Act 1908 (New Zealand).

\section{Table of Cases}

1. M'Naghten's Case (1843) $10 \mathrm{Cl}$ \& Fin; 8 ER 718; [1843-60] All ER Rep 229 (HL).

2. $R v$ Deighton (1900) 18 NZLR 891 (SC).

\section{Bibliography}

1. James Bennett "Fifty Years of Parker and Hulme: A Survey of Some Major Textual Representations and Their Ideological Significance" (2005) 4/5 JNZS 11.

2. Sharon Ellis "Scoop Review: Daughters of Heaven \& The Picture of Dorian Gray- Downstage 3-12 Feb" $\quad(7 \quad$ February 2011) $<$ http://www.scoop.co.nz/stories/HL1102/S00045/scoop-review-daughters-ofheaven-dorian-gray.htm>.

3. Michelanne Forster Daughters of Heaven (Victoria University Press, Wellington, 1992).

4. Michelanne Forster "Five Questions About Daughters of Heaven" (July 2011), Playmarket $<$ http://www.playmarket.org.nz/sites/default/files/images/MISC/5\%20questions\% 20about $\% 20$ daughters $\% 20$ of $\% 20$ heaven-draft $\% 202$.pdf $>$.

5. Glamuzina, Julie and Laurie, Alison Parker and Hulme: A Lesbian View (New Women's Press, Auckland, 1991). 
6. Peter Graham So Brilliantly Clever: Parker, Hulme and the Murder That Shocked the World (Awa Press, Wellington, 2011).

7. Gurr, Thomas and Cox, $\mathrm{H} \mathrm{H}$ "Death in a Cathedral City" in Famous Australasian Crimes (Fredrick Muller Ltd, London, 1957) 148.

8. Gurr, Thomas and Cox, H H Obsession (Fredrick Muller Ltd, London, 1958).

9. Bruce Harding "When the 'corpus juris' meets a corpus delicti: The appearance and representation of Law's violence as purveyed in the Hulme-Parker trial [1954] and narrated in Peter Jackson's Heavenly Creatures [1994]" [unpublished].

10. Donald J Hermann The Insanity Defence: Philosophical, Historical, and Legal Perspectives (Thomas, Springfield, Illinois, 1983).

11. John T. McNeil "Natural Law in the Teaching of Reformers" (1946) 26 The Journal of Religion 168.

12. Marian McCurdy "Women Murder Women: Case Studies in Theatre and Film" (MA Theatre and Film Studies Thesis, University of Canterbury, 2007).

13. "Mrs Parker" (8 May 2014) Radio New Zealand $<$ http://www.radionz.co.nz/national/programmes/mrs-parker>.

14. Simester, Andrew P and Brookbanks, Warren J Principles of Criminal Law (4th ed, Thomson Brookers, 2012).

15. William Shakespeare Macbeth (Cambridge University Press, Cambridge, 2008).

16. William Shakespeare The Merchant of Venice (Cambridge University Press, Cambridge, 2003). 
17. Hannah Smith "Challenging Roles for Talented Youngsters" (5 February 2011) Theatreview $<$ http://www.theatreview.org.nz/reviews/review.php?id=3616>.

18. "The Trial of Pauline Yvonne Parker and Juliet Marion Hulme August 1954", $\begin{array}{lll}\text { Christchurch } & \text { City } & \text { Libraries }\end{array}$ $<\mathrm{http}: / /$ christchurchcitylibraries.com/heritage/digitised/parkerhulme/>.

\section{Word count}

The text of this paper (excluding table of contents, abstract, keywords, footnotes, and bibliography) comprises approximately 7956 words. 